\title{
DESCRIPTION OF LEUKOCYT OF SIAM PATIN FISH (Pangasius hypophthalmus) THAT FEED BY ADDITION OF HARUMANIS MANGO SEEDS (Mangifera indica L.)
}

\author{
Mutiara Syaieba ${ }^{*}$, Iesje Lukistyowati $^{2}$, Henni Syawal $^{2}$ \\ ${ }^{1}$ Student of The Faculty of Fisheries and Marine Science University of Riau, Pekanbaru \\ ${ }^{2}$ Lecturer at The Faculty of Fisheries and Marine Science University of Riau, Pekanbaru \\ *syaiebamutiara@gmail.com
}

\begin{abstract}
Harumanis mango seed (Mangifera indica L.) is a natural ingredient that can be used as an immunostimulant. The phytochemical content in harumanis mango seeds ( $M$. indica $\mathrm{L}$.) include tannins, flavonoids, saponins and ascorbic acid. This study aims to get the best dose of adding harumanis mango seed solution ( $M$. indica $L$.) to the feed. The method used was an experimental method with a Completely Randomized Design (CRD) consisting of one factor with four treatment levels which included P0 without the addition of harumanis mango seed solution, $\mathrm{P} 1$ addition of harumanis mango seed solution at a dose of $1.6 \mathrm{~mL} / \mathrm{Kg}$ of feed, $\mathrm{P} 2$ addition harumanis mango seed solution at a dose of $1.8 \mathrm{~mL} / \mathrm{Kg}$ of feed and P3 addition of harumanis mango seed solution at a dose of $2 \mathrm{~mL} / \mathrm{Kg}$ of feed. Test fish used were Siamese catfish ( $P$. hypophthalmus) measuring 8-12 cm which were kept in cages for 60 days. The results showed that administration of harumanis mango seed solution to feed affected the image of leukocytes of Siamese catfish ( $P$. hypophthalmus $)(\mathrm{P}<0,05)$. The best dose is in the treatment of P3 $\left(2 \mathrm{~mL} / \mathrm{Kg}\right.$ of feed) with an average total leukocytes $9.76 \times 10^{4}$ cells $/ \mathrm{mm}^{3}$, leukocrit levels of $1.67 \%$, lymphocytes $82.00 \%$, neutrophils $7.67 \%$, monocytes $10,33 \%$, phagocytic activity $31.67 \%$ and absolute weight growth of $37.70 \mathrm{~g}$, and $95 \%$ survival.
\end{abstract}

Keywords: Leukocyt, Mangifera indica L, Pangasius hypophthalmus

\section{PENDAHULUAN}

Ikan patin siam (Pangasius hypophthalmus) merupakan salah satu komoditas andalan di Provinsi Riau, sehingga permintaan pasar yang tinggi maka menuntut para pelaku usaha budidaya untuk melakukan sistem budidaya intensif agar memperoleh hasil produksi yang optimal. Namun, sistem budidaya intensif yang tidak ditangani dengan baik dapat menimbulkan masalah lingkungan dan wabah penyakit pada ikan.

Penanganan penyakit dengan pemberian antibiotik secara terus menerus dan tidak terkontrol dapat menyebabkan bakteri patogen menjadi resisten, terjadi penimbunan residu obat-obatan di lingkungan perairan serta di dalam tubuh ikan yang dapat menimbulkan efek berbahaya bagi yang mengkonsumsinya (Lukistyowati dan Syawal, 2013). Untuk itu, upaya pencegahan dan pengobatan penyakit ikan pada sistem budidaya sedang diarahkan pada penggunaan imunostimulan dari bahan alami yang terbukti efektif dan aman untuk manusia dan lingkungan (Sukenda et al., 2008).

Salah satu bahan alami yang berpotensi sebagai imunostimulan adalah biji mangga harumanis (Mangifera indica L.). Kandungan fitokimia dalam biji mangga diantaranya terdapat asam askorbat 
(Morales et al., 2002 dalam Widya, 2003), tanin, flavonoid, dan saponin sehingga menunjukkan adanya efektivitas biji mangga sebagai bakterisidal (Prihandani et al., 2016). Priyanto (2012), menyatakan senyawa tanin akan berikatan langsung dengan dinding sel, membran dan protein ekstrakseluler pada bakteri dan dapat menghambat pertumbuhan mikoorganisme atau aktivitas enzim. Senyawa flavonoid dapat berfungsi sebagai antioksidan, antikanker, antibakteri, imunomodulator, antidiabetes, antiinflamasi (Middleton et al., 2000).

Senyawa yang terkandung dalam biji mangga harumanis diharapkan dapat meningkatkan sistem imun dilihat dari total leukosit, leukokrit, diferensiasi leukosit, dan aktivitas fagositosis.

Berdasarkan uraian di atas penulis tertarik untuk melakukan penelitian mengenai gambaran leukosit ikan patin siam ( $P$. hypophthalmus) yang diberi pakan dengan penambahan larutan biji mangga harumanis $(M$. indica L.). Penelitian ini bertujuan untuk mendapatkan dosis terbaik dari penambahan larutan biji mangga harumanis (M. indica L.) pada pakan.

\section{METODE PENELITIAN}

Penelitian ini telah dilaksanakan pada bulan Maret sampai Mei 2019 di Kolam Percobaan dan Laboratorium Parasit dan Penyakit Ikan Fakultas Perikanan dan Kelautan Universitas Riau.

Metode penelitian yang digunakan adalah metode eksperimen dengan menggunakan Rancangan Acak Lengkap (RAL) terdiri dari Satu faktor dengan empat taraf perlakuan, untuk mengurangi tingkat kekeliruan maka dilakukan ulangan sebanyak tiga kali sehingga diperlukan 12 unit percobaan.

Adapun perlakuan yang digunakan dalam penelitian ini adalah:

$\mathrm{P}_{0}$ : Kontrol (tanpa penambahan larutan biji mangga)

$\mathrm{P}_{1}$ : Pemberian pakan dengan penambahan larutan biji mangga 1,6 $\mathrm{mL} / \mathrm{Kg}$ pakan

$\mathrm{P}_{2}$ : Pemberian pakan dengan penambahan larutan biji mangga 1,8 $\mathrm{mL} / \mathrm{Kg}$ pakan

$\mathrm{P}_{3}$ : Pemberian pakan dengan penambahan larutan biji mangga 2 $\mathrm{mL} / \mathrm{Kg}$ pakan

\section{Persiapan Wadah}

Wadah yang digunakan adalah keramba dengan ukuran 1 x 1 x $1 \mathrm{~m}$ yang terbuat dari jaring yang ditempatkan di Kolam Percobaan Fakultas Perikanan dan Kelautan Universitas Riau. Jumlah keramba yang digunakan sebanyak 12 unit, ikan patin siam berukuran 8-12 cm dimasukkan pada masing-masing keramba dengan padat tebar $50 \mathrm{ekor} / \mathrm{m}^{3}$. Air yang digunakan, yaitu air aliran dari waduk Fakultas Perikanan dan Kelautan Universitas Riau.

\section{Pembuatan Larutan Biji Mangga Harumanis (Mangifera indica $\mathbf{L}$.)}

Buah mangga harumanis yang digunakan adalah buah mangga yang telah matang, dikupas dan daging buahnya disisihkan sehingga yang tertinggal hanyalah biji mangga. Selanjutnya dikupas kembali biji mangga hingga didapatkan keping biji, kemudian dicuci dengan air mengalir lalu dikering anginkan selama 20 menit. Setelah kering diparut menggunakan parutan. Hasil parutan diperas menggunakan kain kasa. Hasil perasan disaring kembali menggunakan kertas saring Whatman nomor $42 \mu \mathrm{m}$ sehingga didapatkan larutan stok $100 \%$.

\section{Pembuatan Pakan yang Mengandung Larutan Biji Mangga Harumanis (Mangifera indica L.)}

Terlebih dahulu lakukan perhitungan formulasi pakan yang akan dibuat, diharapkan kandungan pakan mengandung $35 \%$ protein. Kemudian bahan-bahan yang digunakan ditimbang sesuai formulasi. 
Pencampuran bahan dilakukan secara bertahap, mulai dari jumlah yang paling sedikit hingga yang paling banyak agar campuran menjadi homogen. Sedangkan larutan biji mangga harumanis dicampurkan dengan menggunakan air hangat dengan suhu $30^{\circ} \mathrm{C}$ lalu diaduk bersama bahan pakan lainnya. Pelet dicetak dengan alat pencetak pelet, kemudian pelet dikeringkan dengan penjemuran di bawah sinar matahari.

\section{Pemeliharaan Ikan}

Ikan diaklimatisasi di keramba selama 3 hari agar tidak stres. Kemudian ikan diukur dan ditimbang berat tubuhnya sebelum perlakuan. Ikan dipuasakan selama 2 hari, pada hari ke 3 ikan mulai diberi perlakuan dengan memberikan pakan mengandung larutan biji mangga harumanis sesuai dengan dosis yang telah ditetapkan. Pakan diberikan sebanyak $10 \%$ dari bobot biomasa pada pukul 08.00 WIB, 12.00 WIB, dan 17.00 WIB selama 60 hari. Untuk mengetahui pertumbuhan ikan dilakukan sampling setiap 15 hari sekali.

\section{Pengambilan Darah}

Syringe dan mikrotube dibasahi dengan EDTA $10 \%$. Darah diambil menggunakan syringe $1 \mathrm{~mL}$ pada bagian vena caudalis dekat linea lateralis dan dimasukkan dalam mikrotube.

\section{Total Leukosit}

Sampel darah dihisap dengan pipet thoma leukosit hingga skala 0,5 dan ditambah larutan Turk hingga garis 11 . Selanjutnya dihomogenkan dengan cara menggoyangkan pipet membentuk angka delapan. Kemudian dibuang sebanyak dua tetes agar tidak ada gelembung udara. Selanjutnya diteteskan pada kamar hitung haemositometer dan ditutup dengan cover glass. Selanjutnya diamati di bawah mikroskop dengan pembesaran 10 x 40 . Rumus perhitungan total leukosit sebagai berikut:

\section{Total Leukosit $=\sum n \times 50 \mathrm{sel} / \mathrm{mm}^{3}$}

Keterangan :

$\sum n$ : Jumlah total leukosit pada 4 kotak besar

50 : Faktor pengenceran

\section{Leukokrit}

Sampel darah dimasukkan dalam tabung kapiler leukokrit sampai $4 / 5$ bagian tabung, bagian ujung kapiler ditutup dengan crystoseal, kemudian disentrifuge selama 5 menit dengan kecepatan 11.000$12.000 \mathrm{rpm}$ pada sentrifuge (microhematocrit centrifuge Model SH1201) dengan posisi tabung yang bervolume sama berhadapan agar putaran sentrifuge seimbang. Setelah itu diukur persentase dari nilai leukokrit. Kemudian nilai leukokrit yang diperoleh dibaca pada alat baca khusus yaitu microhematocrit reader.

\section{Diferensiasi Leukosit}

Sampel darah dibuat menjadi preparat ulas darah pada object glass lalu dikering anginkan, selanjutnya difiksasi dengan larutan metanol $95 \%$ selama 5 menit, setelah itu dibilas dengan akuades lalu dikering anginkan, dan dilanjutkan dengan pewarnaan Giemsa selama 15 menit, setelah itu dicuci dengan air mengalir, kemudian dikering anginkan. Selanjutnya preparat dapat diamati di bawah mikroskop dengan perbesaran 1000x. Jenis leukosit yang diamati adalah limfosit, neutrofil dan monosit.

\section{Aktivitas Fagositosis}

Sampel darah sebanyak $50 \mu \mathrm{l}$ dimasukan ke dalam mikrotube dan ditambahkan sebanyak $50 \quad \mu l$ suspensi Staphylococcus aereus. Kemudian, suspensi tersebut dihomogenkan dan diinkubasi dalam inkubator selama 20 menit. Selanjutnya suspensi tersebut dibuat menjadi preparat ulas lalu dikering anginkan, selanjutnya difiksasi dengan larutan metanol selama 5 menit. Kemudian dilanjutkan dengan pewarnaan Giemsa selama 15 menit, setelah itu dibilas dengan 
akuades dan kembali dikering anginkan. Selanjutnya preparat dapat diamati di bawah mikroskop dengan perbesaran 1000x. Persentase sel fagositik dihitung dengan cara mengamati sel-sel yang memfagosit bakteri.

\section{Pertumbuhan Bobot Mutlak}

Pertumbuhan bobot mutlak dihitung dengan menggunakan rumus sebagai berikut :

$$
\mathbf{G R}=\mathbf{W t}-\mathbf{W o}
$$

Keterangan :

$$
\begin{aligned}
\mathrm{GR}= & \text { Pertumbuhan mutlak }(\mathrm{g}) \\
\mathrm{Wt}= & \text { Bobot rata-rata ikan pada akhir } \\
& \text { penelitian }(\mathrm{g}) \\
\mathrm{Wo}= & \text { Bobot rata-rata ikan pada awal } \\
& \text { penelitian }(\mathrm{g})
\end{aligned}
$$

\section{Kelulushidupan Ikan}

Kelulushidupan ikan patin siam yang diberi pakan mengandung larutan biji mangga harumanis selama 2 bulan dihitung dengan rumus sebagai berikut :

Keterangan :

$$
\mathrm{SR}=\frac{N t}{N o} \times 100 \%
$$

$\mathrm{SR}=$ Kelulushidupan (\%)
$\mathrm{Nt} \quad=$ Jumlah ikan hidup pada akhir penelitian (ekor)

No = Jumlah yang hidup pada awal penelitian (ekor)

\section{Kualitas Air}

Parameter kualitas air yang diukur selama penelitian adalah suhu, $\mathrm{pH}$, oksigen terlarut (DO) dan amoniak $\left(\mathrm{NH}_{3}\right)$. Pengukuran dilakukan sebanyak dua kali, yaitu pada awal dan akhir penelitian.

\section{Analisis Data}

Data yang diperoleh dari pengukuran total leukosit, leukokrit, diferensiasi leukosit, aktivitas fagositosis, bobot mutlak dan kelangsungan hidup ikan patin siam dianalisis menggunakan analisa variansi (ANAVA) dan uji rentang Student Newman-Keuls. Data kualitas air ditabulasikan dalam bentuk tabel secara deskriptif.

\begin{tabular}{|c|c|c|}
\hline \multirow{2}{*}{ Perlakuan } & \multicolumn{2}{|c|}{ Total Leukosit $\left(x_{10}^{4} \mathrm{sel} / \mathrm{mm}^{3}\right)$} \\
\hline & Pengamatan Hari Ke-0 & Pengamatan Hari Ke-60 \\
\hline $\mathbf{P}_{\mathbf{0}}$ & 8,59 & $8,95 \pm 0,07^{\mathrm{a}}$ \\
\hline $\mathbf{P}_{1}$ & 8,30 & $9,21 \pm 0,15^{\mathrm{b}}$ \\
\hline $\mathbf{P}_{2}$ & 8,46 & $9,37 \pm 0,04^{\mathrm{b}}$ \\
\hline $\mathbf{P}_{3}$ & 8,57 & $9,76 \pm 0,06^{\mathrm{c}}$ \\
\hline
\end{tabular}

\section{HASIL DAN PEMBAHASAN Gejala Klinis Total Leukosit}

Hasil pengamatan total leukosit dapat dilihat pada Tabel 1 .

Tabel 1. Total Leukosit $\left(\times 10^{4} \mathrm{sel} / \mathrm{mm}^{3}\right)$ pada Ikan Patin Siam

Keterangan : P0 : $0 \mathrm{~mL} / \mathrm{Kg} ; \mathrm{P} 1: 1,6 \mathrm{~mL} / \mathrm{Kg} ; \mathrm{P} 2: 1,8 \mathrm{~mL} / \mathrm{Kg} ; \mathrm{P} 3: 2 \mathrm{~mL} / \mathrm{Kg}$.

Berdasarkan Tabel 1 diketahui bahwa setelah 60 hari pemeliharaan, terjadi peningkatan nilai total leukosit, yaitu 8,59$9,76 \times 10^{4} \mathrm{sel} / \mathrm{mm}^{3}$. Peningkatan total leukosit ini terjadi pada setiap perlakuan. Dimana nilai total leukosit tersebut masih dalam jumlah normal, hal ini berdasarkan Royan (2014), bahwa kisaran normal leukosit ikan air tawar adalah 2-15 x $10^{4}$ $\mathrm{sel} / \mathrm{mm}^{3}$.
Hasil uji statistik analisa variasi (ANAVA) menunjukkan bahwa pemberian pakan yang ditambah larutan biji mangga harumanis memberikan pengaruh nyata terhadapat total leukosit ikan patin siam $(\mathrm{P}<0,05)$. Hasil uji lanjut Newman-Keuls menunjukkan bahwa P0 berbeda nyata terhadap P1, P2 dan P3, tetapi P1 dan P2 tidak memberikan perbedaan nyata. 
Total leukosit tertinggi yaitu $9,76 \mathrm{x}$ $10^{4} \mathrm{sel} / \mathrm{mm}^{3}$ diperoleh pada P3 $(2 \mathrm{~mL} / \mathrm{Kg}$ pakan). Peningkatan total leukosit pada $\mathrm{P} 0$ terjadi secara tidak signifikan, hal tersebut disebabkan karena tidak ada penambahan larutan biji mangga harumanis dalam pakan yang diberikan. Hal ini menunjukkan bahwa penambahan larutan biji mangga dalam pakan dapat merangsang peningkatan jumlah leukosit ikan patin siam. Peningkatan jumlah leukosit ini diduga karena adanya respons dari sistem pertahanan tubuh terhadap masuknya senyawa asing yang berasal dari larutan biji mangga harumanis. Menurut Utami et al., (2013), meningkatnya jumlah leukosit di dalam darah menunjukkan bahwa leukosit berfungsi sebagai pertahanan tubuh dapat bereaksi dengan cepat terhadap benda asing atau mikroba yang masuk dalam tubuh ikan.

Peningkatan total leukosit yang terjadi pada $\mathrm{P} 1, \mathrm{P} 2, \mathrm{P} 3$ disebabkan adanya kandungan senyawa yang bersifat imunomodulator, yaitu senyawa yang dapat mengaktifkan dan meningkatkan sel pertahanan tubuh (Pangestika et al., 2012). Senyawa tersebut berupa flavonoid, saponin dan asam askorbat. Menurut Angka et al. (2004) dalam Utami (2009), flavonoid dapat mengaktifkan sistem limfa, sehingga dapat meningkatkan produksi sel darah putih karena masa beredar sel darah putih di dalam darah sangat singkat. Kandungan lain yang dapat meningkatkan sistem imun adalah Saponin. Menurut Francis et al. (2002) dalam Rosmalawati (2008), saponin mempunyai kemampuan merangsang sel imun, yaitu meningkatkan pembentukan antibodi sehingga dapat berperan sebagai immunostimulator. Asam askorbat (vitamin C) juga berperan dalam peningkatan jumlah leukosit, dimana menurut Sibagariang (2010), vitamin C berfungsi sebagai antioksidan yang berperan dalam pemeliharaan dan pembentukkan sel-sel dalam tubuh termasuk sel darah. Peningkatan total leukosit yang terjadi mengindikasikan bahwa telah terbentuknya pertahanan tubuh non spesifik pada ikan patin siam, dimana hal ini akan berperan dalam merespon ketika terjadi infeksi atau sebagai pencegahan terhadap serangan patogen.

\section{Leukokrit}

Pengamatan nilai leukokrit dilakukan untuk mengetahui persentase kadar leukosit dalam darah ikan patin siam. Rata-rata nilai leukokrit ikan patin siam dapat dilihat pada Tabel 2.

Tabel 2. Leukokrit (\%) pada Ikan Patin Siam Selama Pemeliharaan

\begin{tabular}{ccc}
\hline \multirow{2}{*}{ Perlakuan } & \multicolumn{2}{c}{ Total Leukokrit (\%) } \\
\cline { 2 - 3 } & Pengamatan Hari Ke 0 & Pengamatan Hari Ke-60 \\
\hline P0 & 1,67 & $1,33 \pm 0,57$ \\
P1 & 1,33 & $1,67 \pm 0,57$ \\
P2 & 1,33 & $1,67 \pm 0,57$ \\
P3 & 1,67 & $1.67 \pm 0,57$ \\
\hline
\end{tabular}

Keterangan : P0 : $0 \mathrm{~mL} / \mathrm{Kg}$; P1 : 1,6 mL/Kg; P2 : 1,8 mL/Kg; P3: 2 mL/Kg.

Nilai leukokrit tertinggi ada pada $\mathrm{P} 1$, P2, dan P3 (1,67\%), namun masih dalam batas normal, Titrawani (2014) menyatakan bahwa kisaran normal leukokrit pada ikan adalah 1-2 \%. Anderson dan Siwicki (1995) menyatakan bahwa kadar leukokrit dapat digunakan sebagai dasar untuk mengetahui kondisi kesehatan ikan. Bila kadar leukokrit rendah, kemungkinan terjadi infeksi kronis, kualitas nutrisi rendah, kekurangan vitamin serta adanya kontaminan, bila kadar leukokrit tinggi, disebabkan terjadinya tahap awal infeksi dan stres.

Meningkatnya kadar leukokrit pada P1, P2, dan P3 disebabkan karena adanya penambahan larutan biji mangga harumanis 
dalam pakan yang diberikan. Kandungan senyawa flavonoid dalam biji mangga harumanis mampu merangsang organ limfa untuk meningkatkan produksi leukosit, sehingga kadar leukosit dalam darah meningkat. Serta senyawa saponin dan asam askorbat juga ikut berperan merangsang sistem imun tubuh ikan. Berbeda pada $\mathrm{P} 0$, dimana terjadi penurunan rata-rata persentase nilai leukokrit. Hal ini disebabkan karena tidak adanya penambahan larutan biji mangga harumanis dalam pakan yang diberikan.

\section{Diferensiasi Leukosit}

Perhitungan diferensiasi leukosit dilakukan untuk melihat perubahan jumlah dari jenis-jenis leukosit (limfosit, neutrofil dan monosit) yang terjadi selama pemeliharaan. Hasil pengamatan diferensiasi leukosit pada ikan patin siam yang dipelihara dapat dilihat pada Tabel 3.

Tabel 3. Diferensiasi Leukosit Ikan Patin Siam

\begin{tabular}{ccccc}
\hline \multirow{2}{*}{ Pengamatan } & \multirow{2}{*}{ Perlakuan } & \multicolumn{3}{c}{ Diferensiasi Leukosit (\%) } \\
\cline { 2 - 5 } Hari Ke- 0 & L0 & 73,00 & Neutrofil & Monosit \\
& P1 & 71,33 & 12,00 & 15,00 \\
& P2 & 72,33 & 13,00 & 15,67 \\
& P3 & 72,00 & 12,33 & 15,33 \\
Hari Ke-60 & P0 & $75,00 \pm 1,00^{\mathrm{a}}$ & 13,00 & 15,00 \\
\hline & P1 & $77,67 \pm 0,57^{\mathrm{b}}$ & $11,33 \pm 1,53^{\mathrm{b}}$ & $13,67 \pm 1,15^{\mathrm{b}}$ \\
& P2 & $81,00 \pm 1,00^{\mathrm{c}}$ & $8,00 \pm 0,57^{\mathrm{ab}}$ & $12,00 \pm 1,00^{\mathrm{a}}$ \\
& P3 & $82,00 \pm 1,00^{\mathrm{a}}$ & $7,67 \pm 1,52^{\mathrm{a}}$ & $11,00 \pm 1,00^{\mathrm{a}}$ \\
\hline
\end{tabular}

Keterangan : P0 : 0 mL/Kg; P1 : 1,6 mL/Kg; P2 : 1,8 mL/Kg; P3: 2 mL/Kg.

\section{Limfosit}

Persentase limfosit pada 60 hari pemeliharaan berkisar 75,00-82,00\%. Persentase limfosit ini masih dalam kisaran normal sesuai pendapat Preanger et al. (2016) jumlah persentase rata-rata limfosit di dalam darah berkisar antara 71,12$82,88 \%$. Hasil uji statistik analisis variasi (ANAVA), menunjukkan bahwa pemberian pakan yang ditambah larutan biji mangga harumanis memberikan pengaruh nyata terhadapat persentase limfosit ikan patin siam $(\mathrm{P}<0,05)$. Hasil uji lanjut NewmanKeuls menunjukkan bahwa P0 berbeda nyata terhadap P1, P2 dan P3, tetapi P2 dan $\mathrm{P} 3$ tidak memberikan perbedaan nyata.

Persentase limfosit tertinggi ada pada P3 (2 mL/Kg) yaitu $82,00 \%$, sedangkan persentase limfosit terendah ada pada P0 (tanpa penambahan larutan biji mangga harumanis). Peningkatan persentase limfosit ini disebabkan karena adanya kandungan senyawa flavonoid dalam larutan biji mangga harumanis. Flavonoid mampu memacu proliferasi limfosit sehingga terjadi peningkatan jumlah sel limfosit. Menurut Asep (2014), flavonoid dapat memacu proliferasi limfosit dan meningkatkan jumlah sel $\mathrm{T}$.

Meningkatnya persentase limfosit ini juga mengindikasi adanya patogen atau benda asing di perairan yang masuk ke dalam tubuh ikan, sehingga flavonoid merangsang aktivitas sel $\mathrm{T}$ dan sel $\mathrm{B}$. Limfosit berfungsi menyediakan sistem pertahan dari serangan benda-benda asing yang masuk ke dalam tubuh, jumlah limfosit akan mengalami penurunan jika sudah terjadi infeksi patogen (Alifuddin, 1999 dalam Firly et al., 2015).

\section{Neutrofil}

Persentase neutrofil pada 60 hari pemeliharaan berkisar 7,67-11,33\%. Peningkatan sel neutrofil dalam darah diindikasikan bahwa terjadi peradangan akibat masuknya agen penyakit maupun benda asing dalam tubuh (Brown, 2000).

Hasil uji statistik analisis variasi (ANAVA), menunjukkan bahwa pemberian 
pakan yang ditambah larutan biji mangga harumanis memberikan pengaruh nyata terhadapat persentase neutrofil ikan patin siam $(\mathrm{P}<0,05)$. Hasil uji lanjut NewmanKeuls menunjukkan bahwa P0 berbeda nyata terhadap P2 dan P3, tetapi tidak berbeda nyata terhadap P1.

Persentase neutrofil pada P2 dan P3 sudah berada pada kisaran jumlah neutrofil ikan normal, yaitu 6-8\% (Windarti, 2015). Hal ini menunjukan bahwa P2 $(1,8 \mathrm{~mL} / \mathrm{Kg})$ dan P3 (2 $\mathrm{mL} / \mathrm{Kg})$ dapat menghambat infeksi patogen, ditandai dengan penurunan persentase neutrofil. Penurunan neutrofil terjadi karena mengalami autolisis setelah berhasil menekan infeksi dari patogen atau benda asing yang masuk ke dalam tubuh ikan (Jain, 1993 dalam Rustikawati, 2012).

\section{Monosit}

Persentase monosit pada 60 hari pemeliharaan berkisar 10,33-13,67\%. Hasil uji statistik analisis variasi (ANAVA), menunjukkan bahwa pemberian pakan yang ditambah larutan biji mangga harumanis memberikan pengaruh nyata terhadapat persentase monosit ikan patin siam $(\mathrm{P}<0,05)$. Hasil uji lanjut Newman-Keuls menunjukkan bahwa P0 berbeda nyata terhadap P2 dan P3, tetapi tidak terhadap $\mathrm{P} 1$. Penurunan persentase monosit mengindikasikan bahwa monosit telah berhasil mencegah terjadinya infeksi patogen. Selain itu, keberadaan senyawa flavonoid dalam biji mangga harumanis juga membantu kerja monosit. Flavonoid bersifat antiinflamasi dan antimikroba serta mampu mendenaturasi protein pada sel patogen, sehingga infeksi patogen tidak terjadi. Flavonoid berfungsi sebagai antimikroba, antivirus, dan immunostimulan (Naiborhu, 2002). Menurut Hartika (2014), penurunan nilai monosit disebabkan karena ikan dalam kondisi sehat atau kondisi ikan yang semakin membaik setelah adanya serangan dari mikroba atau benda-benda asing, karena monositnya aktif dalam memfagosit mikroba benda asing dan juga sistem imun tubuh kuat sehingga dapat mencegah terjadinya infeksi.

\section{Aktivitas Fagositosis}

Hasil pengamatan aktivitas fagositosis leukosit ikan patin siam selama penelitian dapat dilihat pada Tabel 4 .

Tabel 4. Aktivitas Fagositosis (\%) pada Ikan Patin Siam

\begin{tabular}{ccc}
\hline \multirow{2}{*}{ Perlakuan } & \multicolumn{2}{c}{ Aktivitas Fagositosis (\%) } \\
\cline { 2 - 3 } & Pengamatan Hari Ke-0 & Pengamatan hari ke-60 \\
\hline $\mathbf{P}_{\mathbf{0}}$ & 21,33 & $24,67 \pm 1,53^{\mathrm{a}}$ \\
$\mathbf{P}_{\mathbf{1}}$ & 20,00 & $27,00 \pm 1,15^{\mathrm{b}}$ \\
$\mathbf{P}_{\mathbf{2}}$ & 20,67 & $30,67 \pm 1,00^{\mathrm{c}}$ \\
$\mathbf{P}_{\mathbf{3}}$ & 21,67 & $31,67 \pm 0,58^{\mathrm{c}}$ \\
\hline
\end{tabular}

Keterangan : P0 : 0 mL/Kg; P1 : 1,6 mL/Kg; P2 : 1,8 mL/Kg; P3: 2 mL/Kg.

Berdasarkan Tabel 4, diketahui bahwa persentase aktivitas fagositosis ikan patin siam diawal pemeliharaan berkisar $20,00-21,67 \%$ dan pada 60 hari pemeliharaan persentase aktivitas fagositosis ikan patin siam berkisar 24,67$31,67 \%$. Hasil uji statistik analisis variasi (ANAVA), menunjukkan bahwa pemberian pakan yang ditambah larutan biji mangga harumanis memberikan pengaruh nyata terhadapat persentase aktivitas fagositosis ikan patin siam $(\mathrm{P}<0,05)$. Hasil uji lanjut
Newman-Keuls menunjukkan bahwa P0 berbeda nyata terhadap P1, P2 dan P3, namun pada $\mathrm{P} 2$ dan $\mathrm{P} 3$ tidak menunjukan perbedaan nyata.

Tingginya persentase nilai aktivitas fagositosis menunjukkan bahwa telah terbentuknya sistem pertahanan tubuh pada ikan patin siam. Menurut Utami et al. (2013), meningkatnya aktivitas sel fagosit dari darah menunjukkan bahwa sistem kekebalan dari ikan juga meningkat. Hal ini karena senyawa flavonoid berpotensi 
bekerja terhadap limfokin yang dihasilkan oleh sel $\mathrm{T}$ sehingga akan merangsang selsel fagosit untuk melakukan respon fagositosis (Nugroho, 2012). Keberadaan flavonoid semakin memudahkan sel fagosit untuk melakukan fungsinya dalam memfagositosis antigen karena adanya fungsi opsonin. Opsonin adalah zat yang berfungsi untuk meningkatkan aktivitas fagositosis (Jawetz et al., 2005 dalam Pangestika et al., 2012).

\section{Pertumbuhan Bobot Mutlak}

Rata-rata nilai pertumbuhan bobot mutlak ikan patin siam dapat dilihat pada Tabel 5.

Tabel 5. Pertumbuhan Bobot Mutlak Ikan Patin Siam

\begin{tabular}{ccc}
\hline Perlakuan & Pengamatan Hari Ke-0 $(\mathbf{g})$ & Pengamatan Hari Ke-60 $(\mathbf{g})$ \\
\hline P0 & 4,57 & $18,29 \pm .0,84^{\mathrm{a}}$ \\
P1 & 4,51 & $21,82 \pm 1.07^{\mathrm{b}}$ \\
P2 & 4,94 & $23,12 \pm 2.10^{\mathrm{b}}$ \\
P3 & 4,77 & $37,70 \pm 1.50^{\mathrm{c}}$ \\
\hline
\end{tabular}

Keterangan : P0 : 0 mL/Kg; P1 : 1,6 mL/Kg; P2 : 1,8 mL/Kg; P3: 2 mL/Kg.

Berdasarkan Tabel 5 diketahui bahwa nilai rata-rata pertumbuhan bobot ikan patin siam yang dipelihara dengan pemberian pakan yang ditambah larutan biji mangga harumanis setelah 60 hari berkisar 22,8642,47 g/ekor. Berdasarkan uji statistik variasi (ANAVA), menunjukkan bahwa pemberian pakan dengan penambahan larutan biji mangga harumanis berpengaruh nyata terhadap pertumbuhan bobot mutlak ikan patin siam $(\mathrm{P}<0,05)$. Hasil uji lanjut Newman-Keuls diketahui bahwa P3 berbeda nyata berhadap $\mathrm{P} 0, \mathrm{P} 1$, dan $\mathrm{P} 2$. Namun pada P1 dan P2, tidak menunjukan perbedaan nyata.

Pertumbuhan bobot mutlak ikan patin siam yang diberi pakan dengan penambahan larutan biji mangga harumanis pada 15 hari pertama masih relatif sama dan tidak menunjukan perbedaan yang signifikan. Pada pemeliharaan hari ke 30, pertumbuhan bobot mutlak ikan patin siam mulai menunjukan perbedaan yang signifikan, terutama pada perlakuan yang diberi penambahan larutan biji mangga harumanis pada pakan (P1, P2, dan P3). Pada pemeliharaan hari ke 45 , perbedaan yang signifikan semakin terlihat pada P3 (2 $\mathrm{mL} / \mathrm{Kg}$ pakan) yang menunjukan perbedaan pertumbuhan lebih cepat dari $\mathrm{P} 0, \mathrm{P} 1$, dan P2, hal ini terus berlanjut hingga akhir pemeliharaan.

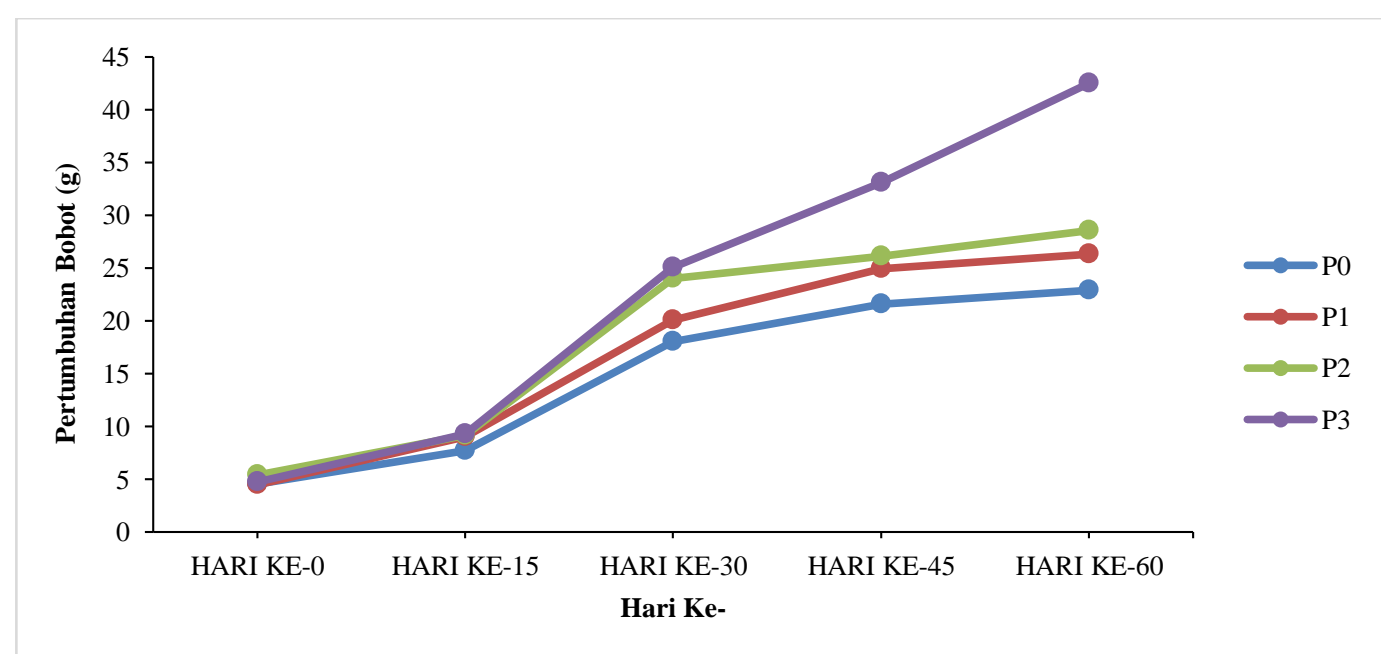

Gambar 1. Pertumbuhan Bobot Ikan Patin Siam (Pangasius hypophthalmus) 
Berdasarkan Tabel 4 dan Gambar 1 dapat dilihat bahwa Pemberian larutan biji mangga harumanis dalam pakan diketahui dapat meningkatkan pertumbuhan bobot mutlak ikan patin siam. Diketahui bahwa pertumbuhan bobot mutlak tertinggi adalah 37,70 g/ekor terjadi pada P3, hal ini disebabkan oleh kandungan biji mangga harumanis berupa vitamin $\mathrm{C}$ juga memberikan pengaruh terhadap pertumbuhan bobot mutlak ikan patin siam, dimana vitamin $\mathrm{C}$ berperan sebagai katalisator proses metabolisme dalam tubuh. Nutrisi yang diserap oleh tubuh haruslah dimetabolisme terlebih dahulu.
Hal ini sesuai dengan pernyataan Listianingrum (2015) bahwa vitamin C merupakan senyawa organik yang berperan dalam proses metabolisme makanan dan fisiologis ikan, meskipun bukan sebagai sumber tenaga tetapi vitamin $\mathrm{C}$ dibutuhkan sebagai katalisator terjadinya metabolisme di dalam tubuh.

\section{Keluluhidupan Ikan}

Kelulushidupan ikan patin siam yang dipelihara selama 60 hari dengan diberi pakan yang ditambah larutan biji mangga harumanis dapat dilihat pada Tabel 6.

Tabel 6. Rata-rata Nilai Kelulushidupan Ikan Patin Siam (Pangasius hypophthalmus)

\begin{tabular}{ccc}
\hline Perlakuan & Pengamatan Hari Ke-0 $(\%)$ & Pengamatan Hari Ke-60 $(\%)$ \\
\hline P0 & 100 & 63,33 \\
P1 & 100 & 83,33 \\
P2 & 100 & 90,67 \\
P3 & 100 & 95,33 \\
\hline
\end{tabular}

Keterangan : P0 : 0 mL/Kg; P1 : 1,6 mL/Kg; P2 : 1,8 mL/Kg; P3: 2 mL/Kg

Berdasarkan Tabel 6, diketahui bahwa kelulushidupan ikan patin siam yang diberi pakan mengandung larutan biji mangga harumanis (P1, P2, dan P3) lebih tinggi dibandingkan dengan yang tidak diberi perlakuan (P0). Rendahnya persentase kelulushidupan pada P0 diperkirakan salah satunya karena proses pengambilan darah yang menyebabkan luka pada tubuh ikan patin siam sehingga meningkatkan potensi terjadi infeksi sekunder oleh patogen yang ada di perairan. Berbeda pada P1, P2, dan P3 yang memiliki sistem pertahanan tubuh yang lebih baik. Hal ini dikerenakan adanya senyawa flavonoid, tanin dan saponin dalam biji mangga harumanis, yang mana senyawa-senyawa tersebut bersifat antibakteri, antiinflamasi, dan imunostimulan. Kandungan fitokimia dalam biji mangga harumanis diantaranya terdapat tanin, flavonoid, dan saponin sehingga menunjukkan adanya efektivitas biji mangga harumanis sebagai bakterisidal (Prihandani et al., 2016).
Vitamin $\mathrm{C}$ yang terkandung dalam biji mangga harumanis berperan dalam mempercepat proses penyembuhan luka pada ikan. Menurut Rachimi (2014) vitamin $\mathrm{C}$ berperan membantu dalam pembentukan kolagen dan mempercepat proses penyembuhan luka pada ikan. Tingginya nilai kelulushidupan pada perlakuan $\mathrm{P}_{3}$, hal ini dikarenakan adanya penambahan larutan biji mangga harumanis dalam pakan yang mampu menghambat serangan benda-benda asing atau patogen yang ada di perairan dan dapat meningkatkan sistem pertahan tubuh ikan.

\section{Kualitas Air}

Air sebagai media hidup ikan memegang peranan penting dalam kelangsungan hidup organisme yang ada didalamnya, termasuk ikan. Sehingga perlu diperhatikan beberapa parameter kualitas air. Hasil pengukuran parameter kualitas air ikan patin siam selama pemeliharaan dapat dilihat pada Tabel 7 . 
Tabel 7. Kisaran Parameter Kualitas Air

\begin{tabular}{lccc}
\hline \multirow{2}{*}{ Parameter } & \multicolumn{3}{c}{ Kisaran Parameter Kualitas Air } \\
\cline { 2 - 4 } & Awal & Akhir & Baku Mutu SNI \\
\hline Suhu $\left({ }^{\circ} \mathrm{C}\right)$ & $27-30$ & $28-30$ & $25-30$ \\
$\mathrm{Ph}$ & $5,2-6,5$ & $6,2-7$ & $6,5-8,5$ \\
$\mathrm{DO}(\mathrm{mg} / \mathrm{L})$ & $3,4-3,8$ & $3,6-3,9$ & $>4$ \\
$\mathrm{NH}_{3}(\mathrm{ppm})$ & $0,017-0,019$ & $0,020-0,024$ & $<0,01$ \\
\hline
\end{tabular}

Keterangan : SNI 01-6483.5-2002 Ikan Patin Siam (Pangasius hypophthalmus)

\section{KESIMPULAN DAN SARAN}

Kesimpulan

Berdasarkan hasil penelitian dapat disimpulkan bahwa ada pengaruh penambahan larutan biji mangga harumanis pada pakan terhadap gambaran leukosit ikan patin siam $(P$. hypophthalmus) dilihat dari adanya peningkatan total leukosit, leukokrit, diferensiasi leukosit, dan aktivitas fagositosis. Dosis terbaik terdapat pada P3 $(2 \mathrm{~mL} / \mathrm{Kg})$ dengan rata-rata total leukosit $9,76 \times 10^{4} \mathrm{sel} / \mathrm{mm}^{3}$, kadar leukokrit sebesar $1,67 \%$, limfosit $82,00 \%$, neutrofil $7,67 \%$, monosit 10,33\%, aktivitas fagositosis $31,67 \%$, pertumbuhan bobot mutlak sebesar $37.70 \mathrm{~g}$, dan kelangsungan hidup $95 \%$.

\section{Saran}

Berdasarkan hasil penelitian dapat disarankan perlunya dilakukan penelitian lanjutan untuk melihat gambaran histopatologi ikan patin siam $(P$. hypopthalmus) yang diberi pakan yang mengandung larutan biji mangga harumanis (M. indica L.).

\section{DAFTAR PUSTAKA}

1. Anderson, D. P., and A. K. Siwicki. (1993). Basic Hematology and Serology for Fish Health. Programs. Second Symposium on Diseases in Asian Aquaculture Aquatic Animal Health and the Enviroment. Phuket, Thailand, Volume : 2, Pages : 185-202.

2. Asep, E. S., S. A. Sumiwi., M. I. Barliana., A. D. Aryanti. (2014). Aktivitas Imunomodulator Ekstrak Etanol Daun Tempuyung (Sonchus arvensis Linn.). Indonesian Journal of Pharmaceutical Science and Technology, Volume : 1(2), Pages : 65-72.

3. Brown K. M. T. (2000). Applied fish pharmacology. Kluwer Academic Publisher, The Netherland.

4. Firly, W. R., G. Mahasri., L. Sumartiwi. (2015). Pengaruh Pemberian Ekstrak Sargassum sp. dengan Pelarut Metanol pada Pakan Terhadap Jumlah Erittrosit dan Diferensiasi Leukosit Ikan Lele Dumbo (Clarias gariepinus). Jurnal Ilmiah Perikanan dan Kelautan, Volume : 7(2), Pages : 213-218.

5. Hartika, R., Mustahal., A. N. Putra. (2014). Gambaran Darah Ikan Nila (Oreochromis niloticus) dengan Penambahan Dosis Probiotik yang Berbeda dalam Pakan. Jurnal Perikanan dan Kelautan, Volume: 4 (4), Pages : 256-267.

6. Handayani, I., E. Nofyan, M. Wijayanti. (2014). Optimasi tingkat pemberian pakan buatan terhadap pertumbuhan dan kelansungan hidup ikan patin jambal (Pangasius djambal). Jurnal Akuakultur Rawa Indonesia, Volume : 2 (2), Pages : 175-187.

7. Listianingrum, N. (2015). Pengaruh Penambahan Vitamin C dalam Pakan Terhadap Gambaran Darah Ikan Gurami (Osphronemus gouramy). Skripsi. Universitas Muhammadiah Purwokerto, Purwokerto.

8. Lukistyowati, I., dan Syawal, H. (2013). Potensi Pakan yang Mengandung Sambiloto (Andrographis paniculata) dan Daun Jambu Biji (Psidium guajava) untuk 
Menanggulangi Bakteri Aeromonas hydrophila pada Ikan Baung (Mystus nemurus). Jurnal Akuakultur Rawa Indonesia, Volume : 1(2), Pages :135-147.

9. Middleton E. C, Kandaswami C, Theoharides TC. (2000). The Effects of Plant Flavonoids on Mammalian Cells: Implications for Inflammation, Heart Disease, and Cancer. Pharmacological Reviews, Volume : 52, Pages : 673-751.

10. Naiborhu P. E. (2002). Ektraksi dan Manfaat Ekstrak Mangrove (Sonneratiaalba dan Sonneratiacaseolaris) sebagai Bahan Alami Antibakterial pada Patogen Udang Windu, Vibrio harveyi. Tesis. Institut Pertanian Bogor, Bogor.

11. Nugroho Y. A. (2012). Efek Pemberian Kombinasi Buah Sirih (Piper betle L) Fruit, Daun Miyana (Plectranthus secutellariodes (L.) R.BR) Leaf, Madu dan Kuning Telur Terhadap Peningkatan Aktivitas dan Kapasitas Fagosit Sel Magrofag. Media Litbang Kesehatan, Volume 22 (1), Pages : 1-5.

12. Pangestika, D. M, Erna. Mashoedi, Imam D. (2012). Pengaruh Pemberian Kunyit (Curcuma domestica Val.) Terhadap Aktivitas Fagositosis Makrofag Psada Mencit BALB/C Yang Diinokulasi Bakteri Listeria Monocytogenes. Skripsi. Universitas Islam Sultan Agung Semarang, Semarang.

13. Preanger, C., I. H. Utama., I. M. Kardena. (2016). Gambaran Ulas Darah Ikan Lele di Denpasar Bali. Fakultas Kedokteran Hewan. Universitas Udayana. Indonesia Medicus Veterinus, Volume: 5 (2), Pages : 96-103.

14. Prihandani, S. S, Noor. M. S, Adriani, Masniari. P. (2016). Efektivitas Ekstrak Biji Mangga Harumanis terhadap Staphylococcus aureus, Bacillus subtilis, Shigella sp., dan Escherichia coli. Jurnal Veteriner, Volume :17 (1), Pages : 45-50.

15. Priyanto R. A. (2012). Aktivitas Antioksi dan Komponen Bioaktif pada Buah Bakau (Rhizophora mucronata). Skripsi. Institut Pertanian Bogor, Bogor.

16. Rachmi., Hambali., Sunarto. (2014). Pengaruh Vitamin C pada Pakan Buatan Terhadap Pertumbuhan dan Kelangsungan Hidup Benih Ikan Tengadak (Barbonymus schwanenfeldii). Jurnal Ruaya, Volume : 3 (1), Pages : 9-16.

17. Rustikawati, I. (2012). Efektifitas Esktrak Sargassum sp. Terhadap Diferensiasi Leukosit Ikan Nila (Orechromis niloticus) yang Diinfeksi S. Iniae. Jurnal Akuatika, Volume : 3 (2), Pages : 123-134.

18. Rosmalawati, N. (2008). Pengaruh Penggunaan Tepung Daun Sembung (Blumea balsamifera) Dalam Ransum Terhadap Profil Ayam Broiler Periode Finisher. Skripsi. Institute Pertanian Bogor, Bogor.

19. Royan, F. (2014). Pengaruh Salinitas yang Berbeda terhadap Profil Darah Ikan Nila (Oreochromis niloticus). Journal of Aquaculture Management and Technology. Volume : 3(2), Pages : 109-117.

20. Sibagariang, E., E, Julianie., Rismalinda., Nurzannah., S. (2010). Buku Saku Metodologi Penelitian untuk Mahasiswa Diploma Kesehatan. Jakarta: Trans Info Media.

21. Sukenda, Jamal S. L, Wahjuningrum D, Hasan A. (2008). Penggunaan Kitosan Untuk Pencegahan Infeksi Aeromonas hydrophila Pada Ikan Lele Dumbo Clarias sp. Departemen Budidaya Perairan. Fakultas Perikanan dan Ilmu Kelautan. IPB. Bogor. Jurnal Akuakultur Indonesia. Volume : 7(2), Pages : 159-169.

22. SNI 01-6483.5-2002 Ikan Patin Siam (Pangasius hypophthalmus) Bagian 5: Produksi kelas pembesaran di kolam.

23. Utami W. P. (2009). Efektifitas Ekstrak Paci Paci (Leucas lavandulaefolia) Yang Diberikan Lewat Pakan Untuk Pencegahan dan Pengobatan Penyakit Motile Aeromonas Septicemia Pada Ikan Lele Dumbo Clarias sp. Skripsi. Institut Pertanian Bogor, Bogor. 
24. Utami, D. T., S. B. Prayitno., S. Hastuti, dan Santika. (2013). Gambaran Parameter Hematologis pada Ikan Nila (Oreochromins niloticus) yang Diberi Vaksin DNA Streptococcus iniae dengan Dosis Berbeda. Journal of Aquaculture Management and Technology, Volume : 2 (4), Pages : 7-20.

25. Windarti., C. Pulungan., N.A. Pamungkas., M.S. Riauwaty., N. Asiah., dan B. Heltonika . (2015). Buku Ajar Fisiologi Hewan Air. Ur Prees : Pekanbaru.

26. Widya, Deasy. (2003). Proses Produksi dan Karakteristik Tepung Biji Mangga Jenis Arumanis (Mangifera indica L.). Skripsi. Institut Pertanian Bogor, Bogor.

27. Zaminati NA. (2017). Pengaruh Kitosan dalam Meningkatkan Respon Imun NonSpesifik pada Ikan Patin Siam Pangasius hypophthalmus yang Diinfeksi Bakteri Aeromonas hydrophila. Tesis.. Universitas Muhammadiyah Purwokerto, Purwokerto.

28. Zulvia, Faridatul. M. Aufia, W. Masitha, N. (2017). Uji Aktivitas Antibakteri Ekstrak Etanol Biji Mangga (Mangifera indica L.) Terhadap Propionibacterium acnes. Jurnal Pharmasipha, Volume : 1(1), Pages : 31-35. 